\title{
Memory and Oblivion. Testimonies and Depictions
}

\author{
Eugenia Meyer \\ Universidad Nacional Autónoma de México, México \\ e-mail: emclio@unam.mx
}

Received: 14 March 2012; Accepted: 10 April 2012; Published online: 15 May 2012

\begin{abstract}
If everything is history, then, in his work, the historian acknowledges both memory and oblivion when creating those depictions that constitute his never-ending commitment, and hence assumes the responsibility of creating and preserving new sources for a new history. Recovering memory and combating oblivion signify a challenge to ceaselessly denounce injustices.

One endeavors to write a history that recovers and preserves different versions of the facts, seen from the most diverse viewpoints and in the light of all manner of interests, and this implies carrying out a task that precedes that of deconstruction, so as to subsequently embark on the heroic feat of splitting hairs, while taking into account different opinions and viewpoints that express the events themselves in many ways. In short, the historian is both a witness of -and a protagonist in- his times.
\end{abstract}

KEYWORDS: individual and social portrayals; subjectivity and bias; ever-written Histories; Histories of the world; Histories of power use and abuse; forgive but not forget.

Citation / Cómo citar este artículo: Meyer, E. (2012) "Memory and Oblivion. Testimonies and Depictions". Culture \& History Digital Journal 1(1): e005. doi: http://dx.doi.org/10.3989/chdj.2012.005

RESUMEN: Memoria y olvido. Testimonios y representaciones.- Si todo es historia, el oficio de historiar reconoce tanto la memoria como el olvido en la construcción de representaciones que se signifiquen como compromiso permanente del historiador. En consecuencia, asume la responsabilidad de generar y salvaguardar nuevas fuentes para una nueva historia. Recuperar la memoria y luchar en contra del olvido presuponen un desafío que se significa como denuncia permanente.

Se intenta una historia que recupere y salvaguarde las diferentes versiones de los hechos, desde las ópticas e intereses más diversos. Ello conlleva una tarea previa de deconstrucción, para luego dar paso a la hazaña de hilar fino, atendiendo a voces y miradas diversas que expresan en formas múltiples el propio acontecer. A fin de cuentas, el historiador como testigo y protagonista de su tiempo.

PALABRAS CLAVE: representaciones individuales y sociales; subjetividad y parcialidad; historias en permanente construcción; historias del mundo; historias de usos y abusos del poder; perdonar mas no olvidar

Copyright: (C) 2012 CSIC. This is an open-access article distributed under the terms of the Creative Commons Attribution-Non Commercial (by-nc) Spain 3.0 License. 
Nobody knows anything about anybody... El perseguidor, Julio Cortázar

Memory and oblivion are both salient aspects of the historian's task, since they contribute to a clearer, more exact knowledge of past, remote, or recent processes. There has been much insistence on the need to lend validity to the historian's commitment, which is closely linked to his ability to bear witness to his times and to change, and also to be an eye witness to, and critic of, the past.

Now, if we agree that everything is history, then we must perforce acknowledge that the historian is faced with an enormous challenge, since his heuristic resources assume heretofore unimagined dimensions. Thus it is important to reassess the historian's job as one that is very intrepid and involves the mind-boggling task of locating, discovering, and at times creating, sources. So much is this so that nowadays, besides the traditional written documents, we are faced with a very wide variety of new historical sources that promise to help create a new history.

Several years ago, the writer, Javier Cercas, who, in his novels, always has recourse to history in order to portray the past, heeded the warnings of Pierre Nora and Élie Barnavi about engaging in the false debate about so-called historic memory when the focus should be on history per se rather than on memory.

This emphasis on historic memory rather than on history itself implies the intrusion of the former into the latter, which has traditionally been seen by historians as just one more source, though, of late, a battle -in our view a spurious and futile one- has nonetheless raged about the notion of conquering history so that it can perforce be placed at the service of memory, perhaps even being appropriated by it. Cercas concluded that history "cannot serve memory, but only truth, since memory, by its very definition, is the opposite of truth, being partial, personal and subjective, while history should aspire to being, if not total and universal, then at the very least objective." (Cercas, 2008:8).

In principle this sounds fine, but we historians find that we need to advance certain objections, since there are many truths, rather than just one, and the writing of history, which is after all a human endeavor, is partial, personal and subjective, since history has at last managed to cast off the chains of positivism, moving away from the utopian concepts of absolute truth and total objectivity.

Hence, a new, emancipating trail is being blazed for memory, oblivion and their different forms of depiction. A year before being awarded the Nobel Prize, Mario Vargas Llosa, uneasy about what was happening in his home country, lamented the fact that the Peruvian government had rejected a donation of two million dollars offered by the German government for the building of a memorial museum devoted to commemorating the crimes committed by terrorists and paramilitary forces during the 1980's and 1990's. The person responsible for this unwonted and disturbing refusal was the Peruvian Minister of Defense, who, let it be said and as the writter pointed out, "is not a gold-braid-laden gorilla with sawdust where his brain should be", but a lawyer with a distinguished professional and political track record, who was, indeed, his country's emissary to the Organization of American States (Vargas Llosa, 2009:25).

As has occurred in many other Latin American countries that have also endured dictatorships, Peru proceeded to set up a Truth and Reconciliation Commission to ascertain the dimensions of the social tragedy that had befallen its citizens between 1980 and 2000. In due time, this commission, headed by the respected thinker, philosopher and former president of the Pontifical Catholic University of Peru, Salomón Lermen, organized an unprecedented exhibition entitled "Yuyanapaq" (a Quechua word meaning 'to remember'). On show were photographs, movies, charts and various other exhibits attesting to the terrorist acts committed in Peru by the Shining Path (Spanish: Sendero Luminoso) Maoist organization, the Túpac Amaru revolutionary movement, the commandoes of the Special Forces, and other paramilitary groups that inflicted a period of terror, helplessness and desperation on the poorest, most vulnerable sectors of society.

Then, as now, the intention was to emphasize the importance of individual, collective and social memory, as expressed in various manifestations aimed at deconstructing the past and hence preventing revisionism, defined as the sort of denial or distortion of the facts that occurs from time to time for political reasons and hampers the historian in his work.

Of course, this position means accepting that history is always being constructed, precisely because it sets out to acknowledge and/or discover the different truths in order to proceed to build histories that can be recognized by eye witnesses and understood by subsequent generations, all of which implies a state of permanent dissatisfaction and a constant endeavor to listen and pay heed to the manifold voices and diverse expressions of those who seek to be heard and cry out for justice. These are the histories of those who have no history -histories that seek to contradict, deny, and even refute, official, institutionalized positions. The viewpoints and memories of anonymous protagonists become -perhaps involuntarily- fundamental sources in the struggle to keep alive pasts that are hazy, forgotten or simply buried. Most 
certainly, by recording the mundane history of a life lived at a specific time, in particular circumstances, lost among so many other lives, we can help to safeguard the "realms of memory" (Nora, 1984).

Often this means confronting state-sanctioned 'truths' that must run the gauntlet of confrontation, questioning and substantiation, assuming that there are so many truths as there are testimonies, and that all of them, without exception, deserve to be heard, heeded, listened to, recovered and preserved. In order to achieve this, the historian sets down experiences occurring at a given time in the lives of specific individuals, which, in due time and at a given moment, become collective and able to be solidly linked to circumstances and events. In his endeavor to understand, assimilate, digest and, above all, explain the facts, the historian ends up becoming the accomplice of the protagonists and struggles against oblivion by awakening memory, fomenting reportage and eliciting value judgments i.e. the narrator's account of the events and his/her thoughts and feelings about them. In this very intimate, complex and honest process, no political, social, individual -or even chronological- idées fixes should intrude between the historical subject and the historian.

Those of us who devote ourselves to building current histories, especially social ones, are often amazed to find people who are willing to share their past, regardless of whether it is painful or traumatic, because they understand that only with their support, their trust and their guidance can we achieve our aim of first understanding the past and then explaining it with an eye to the future.

The memories of the historical subject are always transmitted after being sifted, socialized, made a part of collective memory and, even, compared with the official memory of the events that the said subject experienced.

In this regard, it is of the essence that we address the very real phenomenon of oblivion ${ }^{1}$, which must be faced and combated; it is indispensable that we allude to the forms that this oblivion takes, to the abuses that we become inured to and, above all, that we be conscious of what enables us to filter, preserve or hold fast to the permanent building of memory. As we are reminded by Nietzsche's lapidary observation that for something to remain in the memory, it must be engraved there in letters of fire, it is imperative that we fully recollect in order not to forget. For when memory is expunged, denial or forgetfulness may ensue, at times manifesting themselves as amnesty, or, even worse, amnesia.

We cannot pass over the ceaseless effort to deny or ignore the facts, whether individual or collective, on the grounds that the past is not only forgotten, but disappears. Among those murderers of memory referred to by Vidal-Naquet (1994) are those, for example, who, as part of a "revisionist drift", deny the massacres of the Spanish Civil War that have been swept under the carpet or given the lie for so long, the Holocaust, the genocides that occurred in Africa and Asia, the crimes that took place during the dirty wars in Latin America, and the many other atrocities that characterized the 20 th century and the incidences of which seem to be increasing dramatically at the onset of this new millennium.

In all cases, there is a persistent and willful intention to forget or erase these histories, on the part either of the executioners or of the survivors of the atrocities themselves, whereby the latter attempt to deny the pain and humiliation that they suffered, while the former conveniently avoid atoning for their crimes, wiping the slate clean.

While it is true that memory is not history and that the two may be in conflict with -and even opposed to- each other, it is a matter of rescuing memory from oblivion. Remembering and forgetting are very complex processes, and even more so when they occur at the collective level. When we contemplate a people that remembers, rather than forgetting, we are aware that this memory has been passed down from generation to generation via the channels and depositaries that are inherent in our cultures and civilizations, whence derives the constant endeavor to recover both individual, subjective and collective memory, transformed into social depictions.

If, as Yates (1996) asserts, the recovery of memory is an art, then we must conclude that it is one in which all of us have been engaged throughout the course of history. And, when we thus recall, the ever-dynamic, constantly enhanced building of memory leads us, via the paths of truth, to understand human beings in all their complexity and accept the errors and atrocities that are committed in the name of all manner of principles, dogmas, fanaticisms and orthodoxies. When we manage to achieve this -and only then- will we human beings be able to forgive, which, without a doubt, implies assimilating either the diverse forms of memory -be they individual, social or collective- or the diverse manifestations of cultural memory and other components of "communicative" memory.

Regardless of which city, country or continent we find ourselves in, we always come across "memorials", museums, commemorative centers or mere stones, bearing inscriptions attesting to past events. We try to ensure that coming generations will become aware of the past, and understand and assimilate it, in the hope that they will thus try and prevent it from being repeated.

An example of this is the need to recover experiences of the Spanish Republic and its struggle against the onset of fascism, which led to a bloody 
war and caused people to be driven into exile. The task of uncovering the truth and recovering the past has become an institutional and official endeavor, and, while this continues to be one of our current concerns, one should insist that it is founded on other prior initiatives that were much less ideologically oriented, being more motivated by the historical need to preserve recollections. Such a case was the effort to recover and record the stories of the people who fled for their lives to Mexico in the late 1930's, never forgetting the country that they were forced to leave and longed to return to.

Outstanding among the memories recorded during that effort are various accounts not just of the Spanish Civil War, but, above all, of the exodus to France, which those involved imagined to be a flight to freedom, though this idea was refuted by the reconstruction of a series of incidents which, for many years, were covered in a protective, almost idyllic, cloak of purported solidarity, finally coming to light with the revelation of such serious violations as the ill treatment and humanrights violations that occurred in the Gours, Sète, Argelès-sur-Mer, Saint Cyprien, Septfonds, Cariones, Le Vernet and Île-Tudy refugee camps in which the refugees were interned against their will, as evidenced in the following testimonies

\begin{abstract}
When we reached the Saint Cyprien camp -right in the middle of winter, by the way- [...] there were around twenty five thousand of us; no buildings had been put up to house us and we were completely at the mercy of the elements [...] I recall that on the first day they gave us a moldy hunk of bread for twenty five... ${ }^{2}$
\end{abstract}

I remember some enormous sand pits where they put us, with the Pyrenees off to one side and biting cold and drizzle and so on [...] They took us there -or, rather, they told us to go there- and at each crossing, of course, they were guarding us ... not just gendarmes [...] Senegalese troops commanded by French officers [...] enormous, hostile-looking black men [...] They took us from Le Perthus to Saint Cyprien. They didn't give us a morsel of food the whole way, or offer us anything, except that in one town -I'll never forget the people there- a FrenchCatalonian town called Alban le Cristal, a line of girls and boys formed along the highway to give us bread. We'd eaten nothing but crumbs throughout the war and to us that warm French bread was a marvel, but it was all we got to eat. In Saint Cyprien they took us to the beach $[\ldots]$ because there was nothing but sand $[\ldots] \ldots$ We were among the last ones to arrive $[\ldots]$ and the place was filled with wounded men and women, everybody on top of everybody else [...] without any medical care whatsoever [...] and penned in by a wire fence that the French sappers had put up, with the Senegalese on the other side standing guard over us [...] You couldn't build huts in the sand [...] you'd hardly made a hole when the seawater flooded in and, at night, frost formed. It got so cold during the night that we all woke up covered in a white layer of it. We had blankets to cover ourselves with, the ones that we'd brought with us. Bit by bit, during the night, we dismantled the fence posts and wire and started to build lean-to's for shelter. The Senegalese were very alarmed and built another fence around us, this time like a military defense - that is, with three rows of fence posts with wire zigzagging between them, of the type used to defend trenches. People started to freeze to death, dropping like flies [...] there were a lot of them, weakened by the war [...] and we somehow survived, because we were determined not to die [...] and not a morning went by that we didn't bury three or four people.

[...] the ones who left alone did so to get out of the concentration camp; it was horrible [...] I've never been in a German concentration camp, but people who were in one have told me that they were better than the shacks that the French gave us [...] then we started to receive help from some Quakers [...] clothes from the English. It was absolutely inhuman treatment. That is, to go into some sand pits - a defeated army in tatters, physically smashed, with an enormous number of wounded and sick men - to spend several weeks stuck in some sand pits, without food, medical care or anything; it's a crime. ${ }^{3}$

Now, many decades later, stories like this have helped to build a social memory in present-day Spain, with the passing of the so-called "Historic Memory Law" on the 26th of December 2007, the aim of which was to acknowledge and expand the rights of -and provide more aid to- those who were victims of persecution or violence during the Civil War and [Franco's] dictatorship, and finally settle accounts with the past. ${ }^{4}$

Under other circumstances, the Nazi concentration camps have been preserved as memorials, to prevent what happened in the past from vanishing or being forgotten and, above all, to ensure that can deny that the Holocaust occurred.

It bears mentioning that, in the late 1900's, a plethora of museums appeared whose purpose was to recall, explain and reevaluate the aforesaid genocide, including the Washington Holocaust Museum, the Yad Vashem Museum in Jerusalem, and the Holocaust Memorial Museum in Berlin, an extraordinary architectural feat, comprising an exhibition area, built by the German Government after its country's reunification in order to commemorate the massacre of Jews in Europe and, evidently, to rediscover and reinterpret the said Shoah, one of the bloodiest periods in German history, which so many people are set on forgetting, and -in contravention of German law, which penalizes such behavior- even on denying. 
In the same vein, one should also mention the South African museum complexes in Pretoria and Johannesburg that commemorate the voortrekkers subsequently called Afrikaners- who set up the apartheid system against which Nelson Mandela struggled. The very singular Apartheid Museum in the latter city commemorates this institutionalized segregation between blacks and whites which is such a blotch on South African history.

The building of that collective memory is one of the main tasks facing historians. As Halbwachs (1979) has so rightly said, the task at hand consists in retrieving the experiences in their entirety and establishing social parameters so as to give clear expression to historical memory in a way that takes stock of temporal plurality and the distinction between quantitative time and that qualitative time which nowadays so fittingly informs the endeavors of the historian.

Clearly a general effort is underway to reconquer the domains of memory by coming to terms with its phenomenology and having recourse to the epistemology of history, in a fight to the last with the hermeneutics of oblivion, which implies constant denunciation and an unending struggle against intolerance. ${ }^{5}$ People are interviewed and testimonies are recorded -regardless of their origin or orientation- so as to alleviate the pain of memory, which is only achieved by preventing that which happened from being forgotten.

Collective imaginaries assume different dimensions when they are expressed, and such recollections take on their own shape. When setting out to disregard canons whose hackneyed nature has rendered them obsolete -"One doesn't talk about that"; "Out of sight, out of mind"; "It hurts me to remember"- we must mount a never-ending battle against oblivion.

The uses and abuses of ideologies and censorship, whether subtle or blatant, bear witness to the different ways of hiding or distorting experiences that have left painful marks, and, in the final analysis, are an affront to our times and our society. ${ }^{6}$

In this regard, the development of greater awareness by the victims of human-rights violations -and their bravery in speaking out, in the certainty that their words will be read and heard, becoming part of an ongoing public outcry against such acts- is of great significance. The role of testimony as self-evaluation assumes exceptional proportions when human existence transcends daily routine, or when, in their everyday lives and in the flesh, people confront dramatic transformations, catastrophes and social upheavals that radically change their lives.

As a rule, when they tell their stories the protagonists gradually recall and reevaluate what happened to them and, with great simplicity and without any fuss at all, are able to describe and share the most dramatic or violent moments with the listener, who, upon hearing about them, discovers new dimensions of pain and a heretofore unparalleled effort not to forget.

Such a case was that of Esterlina Milanés, one of the heroines in the struggle against Batista, who, at the age of almost fifty, faced violence, torture and rape with extraordinary courage. Very generously and without at all losing her composure, Esterlina shared her painful memories with me, and, at the end, gave the impression that a heavy burden of pain had been lifted from her shoulders:

I was horrified; I hardly said a word, and then he elbowed me in the chest, leaving me doubled up [...] they dragged me by the armpits ... one of my shoes fell off ... I had one bare foot and [...] the captain, the senior officer there, a young, good-looking guy said to me:

- So you're the old lady who has so many young lovers?

-I think you're mistaken.

-Mistaken?

- and he punched me in the jaw; they were savages [...] and one of them came and took me away ... despite the blow I'd just received, I wasn't bleeding but I was in agonizing pain, and when I reached the landing of the stairs he gave me a kick that made me drop to my knees - it was a pain [. . .] Then he dragged me to a room so dimly lit that you could hardly see [...] and I realized that I was covered with wounds and surrounded by other prisoners, a sort of dungeon [...] the students kept saying:

-Don't forget this, teacher, don't forget. .

-Then they dragged me because I couldn't walk; I was in pain; my whole body ached; it had swollen up. They brought the sergeant to send for the biggest murderer in all of Cuba [...], Ventura, and he said: - Let's see, old lady; what do you have to say [...]? The guy threw me on the stool. When I came to, two police doctors were injecting me. They were saying:

-We have to wake her up. Get up old lady, get up; you've got to talk.

My mouth was cut to the bone.

And as he was leaving, he looked at me and said:

- Hey, if she doesn't talk by nightfall, kill her.

And the captain answered:

—No, we're not going to kill her; we'll kill her three children [...]

Then four policemen appeared [...] and one of these hooded guys grabbed me, and like animals they held me by the arms and legs. I had my bloomers pulled up; they'd yanked my tailored suit off. I can't explain it clearly; I just felt such an enormous pain that I thought I was dying. They stuck the tip of a plastic umbrella into me; they split my womb in two; they tore everything and punctured my large intestine [...] And the Colombian ambassador said to them: 
-I'm looking for the teacher ... her ... she's over there wounded; hand her over to me.

And then [...] I couldn't walk; the blood spurting out in front of those men $[\ldots]^{7}$

As in so many other cases, the important thing for her and her young students, who were the victims of so many horrors, was not to forget and to always keep these things fresh in their memories, as a way of denouncing them. To keep quite was tantamount to being indifferent and even to being an accomplice. If this were not the case, what could have motivated authors such as Levi (1963) to write La Tregua [The Truce], or led Kertész (2001) to leave behind a testimony such as Sin Destino [Fateless or Fatelessness]?

It would seem that we become aware of things late, but irrevocably: we recall the dropping of the atomic bombs on Hiroshima and Nagasaki in August of 1945 or the atrocities committed by the US army in Vietnam, Abu-Ghraib and Guantánamo. We remember the dark night of Cambodia and Pol Pot's Khmer Rouge; the brutality in Rwanda or the senseless, ongoing human-rights violations in Zimbabwe.

How can one explain this effort to retrieve the memories of such dubious experiences as the disappearance of so many men, women and children during the dirty war in Argentina, denounced a thousand times by the Mothers and Grandmothers of Plaza de Mayo, who refuse to forget? And how on earth can we explain the need to reveal and denounce the torturing of people by the last, decadent dictatorship at the end of the ridiculous Falklands war? Today, through the voices of the victims who have denounced these crimes, we are learning about how the officers in this war intimidated and demoralized their subordinates, most of whom were young men doing their compulsory military service. Thanks to these memories, to the denunciations, to the refusal to forget in the face of the 1986 'Full Stop Law', which absolves those responsible for the 'dirty war' of all responsibility, we know that those boys had neither the weapons or the training to face one of the most powerful navies in the world. Finally, almost three decades later, these denunciations are beginning to be heard and dealt with by the courts, in a stubborn effort to save the memories from the jaws of oblivion. ${ }^{8}$

Having occurred much more recently, right at the beginning of a new century and a new millennium, the events of the 11 th of September 2001 in the USA and of the 11th of March 2004 in Madrid remain fresh in our memories. Most certainly we are enthralled by the determination of today's young people to record the recent past. Now we always have up-to-date information about the Spanish 'indignados' (i.e. outraged ones) or the anger of the young New Yorkers in Zuccotti Park who have occupied Wall Street to protest about their country's economic policies, which have left them without any future. ${ }^{9}$

One is very encouraged by this urgent need to keep memory alive, to repel the onslaughts of oblivion, and to create a world in which people live and let live. Each day, with a certain amount of tribulation -and perhaps even of bewildermentwe are seeing that history is beginning to play an alternative role at this irredeemably conclusive moment. This obliges us not to slacken our pace or let our efforts founder.

In his unchanging commitment to recovering the recent past, the historian struggles to achieve realistic -and, we would add, credible- depictions in order to help reveal and denounce injustices and defend the ethical values of humanity. Without standing on the sidelines in our role as witnesses and protagonists, we must continue to carry out the substantive processes of historical discourse -to wit, the gathering of documentary evidence, elucidation and historical depiction- without forgetting how important it is to express all of this in comprehensible language (Certeau, 1993).

There has been much insistence that the task of history is, when all is said and done, one of remembering human events, whence springs the constant conversion of factual reality into the depictions of social discourse.

\section{ACKNOWLEDGEMENTS}

Some of the ideas set forth in this essay have been taken from a previous paper entitled "The Tyrannies of the Past: Oblivion, Memory and History", which was presented at the international colloquium on "Tolerance and Human Rights: Diversity and Peace", held at the University of São Paulo in Brazil (Laboratory of Studies on Intolerance) [Laboratório de Estudos sobre a Intolerância-LEI] on the 23rd of April 2009.

\section{NOTES}

1. According to Marc Augé, there are three forms of oblivion. To wit:

[...] that of return, the main aim of which is to recover a lost past by forgetting the present and the recent past with which this lost past tends to be confused, in order to reestablish continuity with the older past, eliminate the present perfect and make use of the simple past [...] the second figure is that of suspense, the main aim of which is to recover the present by provisionally splitting it off from the past and the future, and, more precisely, forgetting the future inasmuch as it is identified with the return of the past [...] The third figure is that of the beginning, or, one might say, the new beginning [...] it sets out to recover the future by forgetting the past and creating the conditions for a new birth, which, by its very nature, opens the doors to all the possible futures without affording priority to any of them. (Augé, 1998: 66-67)

2. Interview of Manuel Andújar by Elena Aub in Mexico City on the 26th of December 1979 and the 16th of January 
1980, Instituto Nacional de Antropología e Historia, PHO/10/Esp. 8.

3. Interview of Ángel Palerm Vich by Marisol Alonso in Mexico City on the 1st, 13th and 29th of March, the 5 th of April, the 12th of June, the 14th, 18th, 23rd and 26th of July, and the 19th and 21st of August 1979, Instituto Nacional de Antropología e Historia, PHO/19/13.

4. It suffices to see the example of the growing efforts of the children and grandchildren of the "reds" who were shot for answering the letters written to them by their relatives before they died (Junquera, 2009).

5. As Umberto Eco (1989) has remarked, the art of forgetting is impossible and unachievable, in the end merely complicating recollection.

6. Shortly before he died, Carlos Monsiváis, perhaps paraphrasing Berthold Brecht, lucidly asked himself and us, his readers:

Who protests in Nazi Germany against the mass detentions and deportations of Jews, gypsies and homosexuals? Why are clergymen such as Pastor Martin Niemoller, who publicly opposed the Holocaust, so exceptional? How many members of the worldwide leftist movement paid attention to the denouncements of the trials held in Moscow, Prague, Budapest and West Berlin? Why did no rightists express any moral indignation at Franco's atrocities in Spain, at those of Oliveira Salazar in Portugal, of Trujillo en Santo Domingo, of Somoza en Nicaragua, of Stroessner in Paraguay? Which governments boycotted the South African régime while apartheid was still in place? Morality permits uprisings, and that is also called history (Monsiváis, 2009).

7. Excerpts from an interview with Esterlina Milanés Dantin, in Meyer (2007: 121-127).

8. Stories such as these are to be found all over the American continent. From the far south, be it in Brazil, Chile, Colombia or Bolivia, to Guatemala, Honduras, El Salvador, Haiti and the Dominican Republic, gripping, dramatic accounts of struggles for freedom abound. I neither want to -nor could- omit to mention Mexico, which, though in very different circumstances, has experienced -and is now experiencing- its own dramatic atrocities in which memory plays a key role in the struggle not to forget, to let the world know, to understand. We Mexicans are fully aware of the incidences of racism in our country, the urban guerilla groups, the massacres of indigenous people, the murders of women in Ciudad Juárez in the state of Chihuahua, and the ever-flowing rivers of blood spilled by one side or the other in the battle against drug trafficking.

9. See Chafkin (2012)

\section{REFERENCES}

Augé, Marc (1998), Las formas del olvido. Gedisa, Barcelona.

Cercas, Javier (2008), "Palos de ciego. La tiranía de la memoria", El Pais [EP], Madrid, 2 January 2008. http:// elpais.com/diario/2008/01/02/eps/1199258808_850215.html [accessed 28/April/2012].

Certeau, Michel (1993), "La operación historiográfica", La escritura de la historia, Universidad Iberoamericana.' Mexico.

Chafkin, Max (2012), "Revolution Number 99: An oral history of Occupy Wall Street", Vanity Fair [VF] February 2012: 74-82. http://www.vanityfair.com/politics/2012/02/occupywall-street-201202 [accessed 25/March/2012]

Eco, Umberto (1989), "Sobre la dificultad de construir un Ars Oblivionalis", Revista de Occidente, 100: 9-28.

Kertész, Imre (2001) Sin destino. Acantilado, Barcelona.

Halbwachs, Maurice (1979) La mémoire collective, Presses Universitaires de France (PUF), Paris.

Junquera, Natalia, (2009) "Muero tranquilo y orgulloso...," El Pais [EP], 28 March 2009:14. http://elpais.com/diario/ 2009/03/28/espana/1238194812_850215.html [accessed 25/ March/2012]

Levi, Primo (1963) La tregua. El Aleph, Barcelona.

Meyer, Eugenia (2007) El futuro era nuestro. Ocho cubanas narran sus historias de vida. FCE, UNAM, Mexico.

Monsiváis, Carlos (2009), "Una conciencia tardía pero irreversible", El Universal [EU], 1 February 2009. http://www. eluniversal.com.mx/columnas/76592.html [accessed 25/ $\operatorname{March} / 2012]$

Nora, Pierre ed. (1984), Les lieux de mémoire, Gallimard, Paris. Vargas Llosa, Mario (2009), "El Perú no necesita museos", [EP], 8 March 2009. http://elpais.com/diario/2009/03/08/ opinion/1236466813_850215.html [accessed 25/March/ 2012]

Vidal-Naquet, Pierre (1994), Los asesinos de la memoria, Siglo XXI Editores, Mexico City-Madrid.

Yates, Frances A. (1966), The Art of Memory. The University of Chicago Press. 